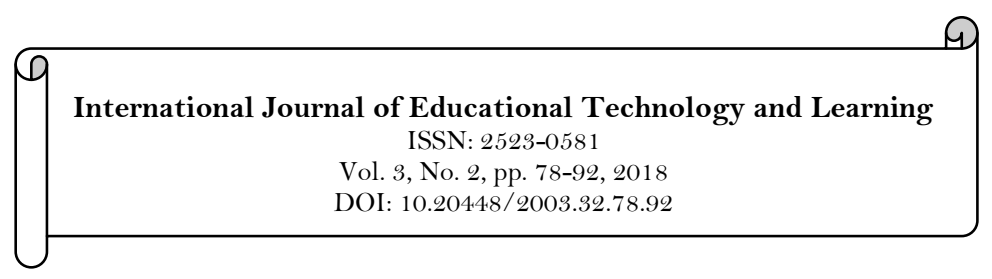

\title{
Comparison of Useful Activities of Improving Awareness in Blended Classes in Java Script and PHP Programming
}

\author{
Isao Miyaji ${ }^{1}$ \\ 'National Institute of Technology, Toyama College (Japan). \\ Emailissusmsi2re@hotmail.co.jp
}

\begin{tabular}{l|l}
\multicolumn{3}{c}{ Abstract } & \\
The grammar in textbook and program examples are explained in a & Keywords: \\
lecture course on JavaScript programming. It was then followed by & Javascript \\
explanation with materials describing program examples to practice & PHP \\
the grammar and exercise problems. We conducted exercises to & $\begin{array}{l}\text { Blended learning } \\
\text { Awareness }\end{array}$ \\
prepare programs in exercise problems with reference to the & Learning activities. \\
program examples. Instructions were given to complete the program & \\
during the lecture course as soon as possible, and the students were & Licensed: \\
asked to submit the program and report files using the functions of e- & This work is licensed under a \\
learning. During the final weeks (Week 14), students were asked to & Creative Commons Attribution \\
prepare a program of voluntary subject he or she came up with, & 4.0 License. \\
execute it and evaluate one another. With reference to the results, & \\
they were asked to correct them by Week 15 and to evaluate one & Publisher: \\
another again. The useful activities for improving awareness were & Scientific Publishing Institute \\
investigated after the lecture course. This paper reports regarding & \\
useful activities for improving awareness. In addition, the result is & \\
explained in comparison with the helpful activities in the PHP & \\
programming taught in the same way. &
\end{tabular}

\section{Introduction}

At present, blended learning is used mainly in institutions of higher education in order to make lecture course effective, efficient and attractive (Bersin, 2004; Miyaji, 2009). The author works on college education to nurture problem-solving abilities by incorporating manufacturing and evaluation in activities (Miyajic \& Yoshida, 2005). It has been suggested that lectures should be supported with increasing the opportunities for various students to learn so that they can make preparations and do reviews "whenever and wherever" with individual support (Central Council for Education, 2012).

As a part of such support, the author reported that implementation of blended lecture combining lecture course organization note, e-learning (learning with lecture slides, learning with exercise problems, mutual learning and evaluation using materials prepared by the students), small tests and so forth was effective [5]. We also reported that the effect could be further improved by increasing the interactions with the teacher when degree of understanding survey was incorporated (Miyajim, Yoshida, \& Naruse, 2007).

Methods to deepen the understanding in PHP and C programming lecture course have been proposed. Of these, blended lecture has been reported to be effective. The report discusses implementing collaborative learning and evaluating the works (Miyajiv \& Yoshida, 2014a; Shinkai \& Miyaji, 2011). It also reports on activities that help improve the awareness (Miyajip, 2015; Miyajis, 2013). Characteristics of various student groups have been reported as the results of cluster analysis of awareness related to programming abilities and classification of awareness and students (Miyajij \& Yoshida, 2014b). It was found that awareness related to abilities improved after the lecture course. Of all types of awareness, it was found that the awareness related to programming improved better than the awareness related to general abilities. It is necessary to learn whether the awareness related to general abilities did not improve because the assignment was difficult, or whether the awareness related to general abilities does not improve much in programming.

We examined and implemented the media necessary for JavaScript programming lecture course using elearning as blended lecture. A class was provided by explaining the answers to the previous assignment first, followed by the lecture on the day's grammar and processing details using slides. Materials describing example exercises and exercise problems on the day's contents are then distributed, and explanation on the 
materials was given using slides. Exercise problems to prepare programs with reference to the grammar, processing details and example exercises were presented later to let the students exercise. Here, the students were asked to prepare programs of their own voluntary themes and evaluate one another to repair the programs with reference to the evaluation results at the end of the term as collaborative learning. The PHP class revealed the results as follows: Students' overall familiarity with programming terms was significantly higher after the course; The increase in attitude scores was greater for programming abilities; The mean scores for "ability to express ideas with PHP", "knowledge of programming techniques", and "ability to read other people's programs and reports” were higher than the overall mean (Miyajiv \& Yoshida, 2014a). The helpful activities in the PHP programming were as follows: "Studying and asking friend questions" was helpful in improving "awareness toward working on problems;" "Activities that involve studying with the textbook" were helpful in improving "understanding of computers and ability to systematically set tasks;" "Activities that involve using applications as well as studying and evaluating other people's programs" were helpful in improving "awareness toward evaluating other people's work;" "Listening to lectures" was helpful in improving "awareness toward programming techniques (Miyajip, 2015)."

About the classes of two different subjects of the same lecture course design, the study that compares term recognition, awareness, and the useful activity is not yet done. In addition, it is not yet examined whether the same learning effect is provided when a similar subject based on the same lecture course design is carried out. Two programming classes to teach JavaScript and PHP languages have been practiced. After the same questionnaire survey was carried out, it is thought that comparing their results has a meaning. The degree of term recognition and awareness was surveyed in JavaScript programming to learn the degree of improvement. The results on the degree of term recognition and awareness were reported (Miyajii, 2016). The differences of term recognition and awareness in blended classes of JavaScript and PHP programming were shown (Miyajia, 2017). Useful activities for improving awareness were investigated after the lecture course. In this paper, results analysed which activities improved which awareness related to abilities are reported. In addition, the results are compared with the useful activities in the PHP programming taught in the same way.

\section{Lecture Course Design and Contents}

As blended lecture, 15 times of 90-minute lectures were given in an optional course on programming in the third-year student in department of information science at University A. Final examination was given to motivate the students and check the degree of their understanding after the fifteenth week. The class for JavaScript programming is explained in the following. As the class for PHP programming is explained in the reference (Miyajip, 2015) the lecture course and contents are omitted in this paper. Lecture course plan is shown in Table 1 for JavaScript programming and in Table 2 for PHP programming. 21 and 24 students took lectures of JavaScript and PHP programming respectively. Instructions were given from the instructor and TA during practices.

On today's internet, web services are provided by dynamically operating programs such as CGI on the web server and making changes on the webpages. The purpose of this lecture course was to learn the JavaScript language, which is popularly used in CGI, and become proficient in basic operation of the program as well as dynamic homepage preparation.

The following objectives were set: (1) Understanding the relationship between server and client, (2) Understanding the Web services, (3) Learning how to use JavaScript, and (4) Learning how to prepare CGIs.

Activities to research, ponder, create, evaluate and correct were also included in lecture course to improve the problem-solving abilities necessary in society.

As the development of the class, lecture was given for approximately 35 minutes using slides based on the grammar and process details in the textbook (Anku, 2011) for the day. Then materials describing the example exercise program and exercise problems on the contents for the day were distributed. Based on these materials, explanation was given on the program using slides for approximately 10 minutes. Then with reference to the grammar, program examples in example exercise and execution examples, the students were asked to practice after presenting an exercise problem to develop programs (approximately 45 minutes). They were allowed to execute and check the process flow and execution results with reference to program example. Those who successfully develop programs for the exercise problem were asked to submit the program and report file to LMS.

As exercise problem, two problems to develop JavaScript programs related to contents of the chapter explained in the lecture were given. One problem was similar to the program example which could be developed by making slight changes to the program example. The other was an application problem for it.

The students were instructed to submit at least one program in one class, and to develop programs for both two problems if they had time. Students were asked to submit the file and another file which was an A4 form report, when a student finished a program. The information described in the report included the program list, execution results and discussion. The grades were given as overall evaluation on submitted materials including exercise problems and assignments as well as regular tests.

During the 13th class, an exercise to design and develop programs such as card games, horoscope, and arithmetic learning that other people can use by using control statements, array and so forth as voluntary 
themes was given. The flow for the process is described as follows: Voluntary theme exercise was explained during the 12 th class with instruction to make preparations so that input data are prepared, and the program can be designed and developed by the next class. (1) During the 13th class, the students developed programs. (2) After distributing the forms to evaluate the others in the 14th class, they executed the developed program. (3) They evaluated one another. (4) They corrected the program with reference to it. (5) During the 15th class in next week, the students executed the corrected programs again. (6) They evaluated one another again. (7) They checked if they were corrected properly. (8) They wrote and submitted reports.

The following were prepared and made available as e-learning functions: (1) Downloading material (lecture course plan, evaluation sheet, framework for exercise report, form for explanation of voluntary themes, framework for report on voluntary themes), (2) Uploading materials to submit (evaluation sheets, exercise reports, programs, reports on voluntary themes), (3) Bulletin board, (4) Mail to ask anything.

The following media were used to give lectures: (1) Textbook, (2) Documents describing lecture course contents and plan, (3) Slides explaining lecture details and plan, (4) Lecture slides, (5) Forms describing program examples and exercise problems, (6) Slides describing program examples and exercise problems, (7) Documents describing voluntary themes, (8) Evaluation sheet file, (9) Report form file, (10) PC, and (11) elearning. 
Table-1. Lecture course plan for JavaScript programming.

\begin{tabular}{|c|c|c|c|c|c|c|c|c|c|c|c|c|c|c|}
\hline \multirow[b]{2}{*}{ 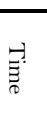 } & \multirow[b]{2}{*}{ Lesson contents } & \multicolumn{9}{|c|}{ Lecture course } & \multicolumn{4}{|c|}{ e-learning } \\
\hline & & $\begin{array}{l}\text { No. of } \\
\text { lesson } \\
\text { slides }\end{array}$ & $\begin{array}{c}\text { Distribution } \\
\text { document }\end{array}$ & Textbook & $\begin{array}{l}\text { No. of pages } \\
\text { of the } \\
\text { textbook }\end{array}$ & $\begin{array}{l}\text { An example } \\
\text { program and } \\
\text { practice }\end{array}$ & $\begin{array}{l}\text { Voluntary } \\
\text { problem }\end{array}$ & $\begin{array}{c}\text { Small } \\
\text { test }\end{array}$ & $\begin{array}{r}\begin{array}{r}\text { Survey of } \\
\text { term } \\
\text { recognition }\end{array} \\
\end{array}$ & $\begin{array}{l}\text { Attitude } \\
\text { survey }\end{array}$ & Downloading & $\begin{array}{l}\text { Program } \\
\text { practice }\end{array}$ & Report & $\begin{array}{l}\text { Evaluation } \\
\text { sheet }\end{array}$ \\
\hline 1 & $\begin{array}{l}\text { About a technique to support } \\
\text { WWW }\end{array}$ & 32 & $\begin{array}{l}\text { Manual of the } \\
\text { lesson plan }\end{array}$ & Chapter o & Hatoson & & & $\begin{array}{l}\text { Small } \\
\text { test }\end{array}$ & $\begin{array}{c}\text { Pre } \\
\text { evaluation }\end{array}$ & $\begin{array}{c}\text { Pre } \\
\text { evaluation }\end{array}$ & $\begin{array}{l}\text { Lecture course } \\
\text { plan, } \\
\text { Evaluation } \\
\text { sheet }\end{array}$ & & & Pre evaluation \\
\hline 2 & $\begin{array}{l}\text { 1.1 Basics of HTML, 1.2, } 1.3 \\
\text { HTML tag }\end{array}$ & 14 & & Chapter 1 & 7 & Exercise 1 & & & & & $\begin{array}{c}\text { Report for } \\
\text { exercise }\end{array}$ & Practice 1 & Practice 1 & \\
\hline 3 & $\begin{array}{l}\text { 1.4 Tables, } 1.5 \text { Frames, } 1.6 \\
\text { Forms, } 1.7 \text { Receipt of data, } 1.8, \\
1.9 \text { Basics of CSS }\end{array}$ & 34 & & Chapter 1 & 12 & Exercise 2 & & & & & & Practice 2 & Practice 2 & \\
\hline 4 & 1.10-1.13 Various styles & 22 & & Chapter 1 & 8 & Exercise 3 & & & & & & Practice 3 & Practice 3 & \\
\hline 5 & $\begin{array}{l}\text { 2.1 Display of the letter in } \\
\text { JavaScript }\end{array}$ & 5 & & Chapter 2 & 4 & Exercise 4 & & & & & & Practice 4 & Practice 4 & \\
\hline 6 & $\begin{array}{l}\text { 2.2-2.6 Reference setting of the } \\
\text { property and method in } \\
\text { JavaScript }\end{array}$ & 20 & & Chapter 3,4 & 8 & Exercise 5 & & & & & & Practice 5 & Practice 5 & \\
\hline 7 & $\begin{array}{l}3.1-3.5 \text { Variables, Type of the } \\
\text { variable, Four operations }\end{array}$ & 24 & & Chapter 3,4 & 12 & Exercise 6 & & & & & & Practice 6 & Practice 6 & \\
\hline 8 & $\begin{array}{l}\text { 3.6-3.8 relational operators, } \\
\text { logical operator, } 4.1,4.2 \text { Branch } \\
\text { sentence (if sentence) }\end{array}$ & 23 & & Chapter 3,4 & 14 & Exercise 7 & & & & & & Practice 7 & Practice 7 & \\
\hline 9 & $\begin{array}{l}\text { 4.3-4.6 Repetition sentence (for } \\
\text { sentence, while sentence, } \\
\text { switch sentence) }\end{array}$ & 18 & & Chapter 4 & 8 & Exercise 8 & & & & & & Practice 8 & Practice 8 & \\
\hline 10 & $\begin{array}{l}5.1-5.3 \text { Definition and call of } \\
\text { the function }\end{array}$ & 13 & & Chapter 5 & 8 & Exercise 9 & & & & & & Practice 9 & Practice 9 & \\
\hline 11 & $\begin{array}{l}\text { 6.1-6.5 Array, Character string, } \\
\text { Mathematics function }\end{array}$ & 23 & & Chapter 6 & 12 & Exercise 10 & & & & & & Practice 10 & Practice 10 & \\
\hline 12 & $\begin{array}{l}\text { 7.1-7.6 Window, Document, } \\
\text { Form, Element object }\end{array}$ & 49 & & Chapter 7 & 16 & Exercise 11 & Manual & & & & Manual & Practice 11 & Practice 11 & \\
\hline 13 & $\begin{array}{l}\text { 7.7-7.12 Location, DOM, and } \\
\text { Object of others, Making the } \\
\text { program of the problem }\end{array}$ & 32 & & Chapter 7 & 10 & & Design & & & & $\begin{array}{c}\text { Report of } \\
\text { voluntary } \\
\text { problem }\end{array}$ & & & Self evaluation \\
\hline 14 & $\begin{array}{l}\text { An evaluation and correction of } \\
\text { the program of the problem }\end{array}$ & & & & & & Program & & & $\begin{array}{l}\text { Voluntary } \\
\text { problem }\end{array}$ & & & & $\begin{array}{l}\text { Peer } \\
\text { evaluation, } \\
\text { Others } \\
\text { evaluation } \\
\end{array}$ \\
\hline 15 & $\begin{array}{l}\text { The reevaluation of the } \\
\text { program of the problem, } \\
\text { making the report }\end{array}$ & & & & & & Correction & & Post & Post & & $\begin{array}{l}\text { Voluntary } \\
\text { problem }\end{array}$ & $\begin{array}{l}\text { Voluntary } \\
\text { problem }\end{array}$ & $\begin{array}{l}\text { Peer } \\
\text { evaluation, } \\
\text { Others } \\
\text { evaluation }\end{array}$ \\
\hline
\end{tabular}


Table-2. Lecture course plan for PHP programming.

\begin{tabular}{|c|c|c|c|c|c|c|c|c|c|c|c|c|c|}
\hline \multirow[b]{2}{*}{$\stackrel{\Xi}{\Xi}$} & \multirow[b]{2}{*}{ Lesson contents } & \multicolumn{7}{|c|}{ Lecture course } & \multicolumn{5}{|c|}{ e-learning } \\
\hline & & $\begin{array}{l}\text { No. } \\
\text { of } \\
\text { slides }\end{array}$ & $\begin{array}{l}\text { Distributed } \\
\text { documents }\end{array}$ & Textbook & $\begin{array}{l}\text { Examples } \\
\text { and } \\
\text { assignments }\end{array}$ & $\begin{array}{c}\text { Self- } \\
\text { imposed } \\
\text { assignment }\end{array}$ & $\begin{array}{l}\text { Survey of } \\
\text { term } \\
\text { recognition }\end{array}$ & $\begin{array}{l}\text { Survey of } \\
\text { attitude }\end{array}$ & $\begin{array}{l}\text { Learning } \\
\text { by lesson } \\
\text { slides }\end{array}$ & Downloading & Program & Reports & $\begin{array}{c}\text { Evaluation } \\
\text { sheet }\end{array}$ \\
\hline 1 & Before beginning PHP & 36 & $\begin{array}{l}\text { Document of } \\
\text { lesson plan }\end{array}$ & & & & Pre survey & Pre survey & & $\begin{array}{l}\text { How to } \\
\text { create PHP } \\
\text { program }\end{array}$ & & & \\
\hline 2 & Basic program & 25 & $\begin{array}{l}\text { How to } \\
\text { create PHP } \\
\text { program }\end{array}$ & Chapter 1 & Example 1 & & & & Chapter 1 & Reprt & & & \\
\hline 3 & Variable & 28 & & Chapter 2 & Example 2 & & & & Chapter 2 & $\begin{array}{c}\text { Evaluation } \\
\text { sheet }\end{array}$ & Assignment 1 & Assignment 1 & \\
\hline 4 & Condition sentence & 42 & & Chapter 3 & Example 3 & & & & Chapter 3 & & Assignment 2 & Assignment 2 & \\
\hline 5 & Repetition sentence & 40 & & Chapter 4 & Example 4 & & & & Chapter 4 & & Assignment 3 & Assignment 3 & \\
\hline 6 & $\begin{array}{l}\text { Array and control } \\
\text { sentence }\end{array}$ & 27 & & Chapter 2 & Example 5 & $\begin{array}{c}\text { Specification } \\
1\end{array}$ & & & Chapter 2 & $\begin{array}{l}\text { Independent } \\
\text { project }\end{array}$ & Assignment 4 & Assignment 4 & $\begin{array}{l}\text { Self } \\
\text { assessment }\end{array}$ \\
\hline 7 & $\begin{array}{l}\text { Mutual use of self- } \\
\text { imposed assignment 1, } \\
\text { Evaluation, Correction }\end{array}$ & & & & & Program & & & & & Assignment 5 & Assignment 5 & $\begin{array}{l}\text { Peer } \\
\text { assessment }\end{array}$ \\
\hline 8 & $\begin{array}{l}\text { Mutual use of self- } \\
\text { imposed assignment 1, } \\
\text { Evaluation }\end{array}$ & & & & Example 6 & Correction & & & & & & & $\begin{array}{l}\text { Peer } \\
\text { assessment }\end{array}$ \\
\hline 9 & Function & 32 & & Chapter 5 & Example 7 & & & & Chapter 5 & & Assignment 6 & Assignment 6 & \\
\hline 10 & $\begin{array}{l}\text { Use of the regular } \\
\text { expression }\end{array}$ & 27 & & Chapter 6 & Example 8 & & & & Chapter 6 & & Assignment 7 & Assignment 7 & \\
\hline 11 & $\begin{array}{l}\text { Use of the character } \\
\text { string function }\end{array}$ & 23 & & Chapter 6 & Example 9 & & & & & & Assignment 8 & Assignment 8 & \\
\hline 12 & Use of the file & 22 & & Chapter 8 & Example 10 & & & & Chapter 8 & & Assignment 9 & Assignment 9 & \\
\hline 13 & Access to a database & 30 & & Chapter 8 & Example 11 & $\begin{array}{c}\text { Specification } \\
2\end{array}$ & & & & & $\begin{array}{c}\text { Assignment } \\
10\end{array}$ & $\underset{10}{\text { Assignment }}$ & $\begin{array}{l}\text { Self } \\
\text { assessment }\end{array}$ \\
\hline 14 & $\begin{array}{l}\text { Mutual use of self- } \\
\text { imposed assignment 1, } \\
\text { Evaluation, Correction }\end{array}$ & & & & & Program & & $\begin{array}{l}\text { Independent } \\
\text { project }\end{array}$ & & & $\begin{array}{l}\text { Assignment } \\
\quad 11\end{array}$ & $\begin{array}{l}\text { Assignment } \\
\quad 11\end{array}$ & $\begin{array}{l}\text { Peer } \\
\text { assessment }\end{array}$ \\
\hline 15 & $\begin{array}{l}\text { Mutual use of self- } \\
\text { imposed assignment } 1 \text {, } \\
\text { Evaluation }\end{array}$ & & & & & Correction & $\begin{array}{c}\text { Post } \\
\text { survey }\end{array}$ & Post survey & & & & & $\begin{array}{l}\text { Peer } \\
\text { assessment }\end{array}$ \\
\hline
\end{tabular}




\section{Analysis Results}

A survey on awareness related to abilities was conducted before and after the lecture course to know the changes in awareness. The useful activities for improving awareness were investigated on the same survey form about the awareness is taken after the lecture course. A cross-tabulation table is created by taking awareness as its row and activity as column. Cluster analysis is conducted using the cross-tabulation which combines two cross-tabulations in JavaScript and PHP to know useful clusters of activities for improving clusters of awareness. Chi-square tests and residual analysis are conducted concerning the cross-tabulation based on the same clusters of activities and awareness. We know difference between useful activities in JavaScript and PHP by comparing results of residual analysis.

Hereafter, it is considered that there is significant different with significance level $5 \%$ in the significance test results. Significance levels $0.1 \%, 1 \%$, and $5 \%$ are indicated as $* * *, * *$, and $*$ respectively.

\subsection{Classification of Awareness through Cluster Analysis Using the Number of Activities that Are Useful in Improving Awareness}

The students replied activities that were useful in raising awareness among 33 kinds of activity see Table 3. The awareness relating to skills consists of 55 types see Table 4 . Activities were counted and a 55 row $\times 33$ column cross-tabulation table was created. Rows contain 55 types of awareness and columns contain 33 types of activities. The numbers chosen in PHP and JavaScript are 2224 and 1509 respectively. Each cell was added up about cross-tabulation table of PHP and JavaScript. The number chosen is 3733 in total.

Table-3. Number of effective activities chosen for raising their awareness.

\begin{tabular}{|c|c|}
\hline Activities & Total \\
\hline O1. Listening to lectures & 1106 \\
\hline o2. Getting an image of the whole lecture & 119 \\
\hline o3. Asking friends questions about lecture topics & 180 \\
\hline O4. Asking a teacher questions about lecture topics & 19 \\
\hline 05. Preparing & 156 \\
\hline 06. Reviewing & 149 \\
\hline O7. Studying using the textbook & 276 \\
\hline o8. Learning through lecture slides & 40 \\
\hline o9. Evaluating about learning through lecture slides & 5 \\
\hline 10. Learning through exercise problems & 204 \\
\hline 11. Evaluating about learning through exercise problems & 22 \\
\hline 12. Studying for the final exam & 48 \\
\hline 13. Asking using mail & 9 \\
\hline 14. Using Excel & 55 \\
\hline 15. Using Word & 43 \\
\hline 16. Writing into BBS & 33 \\
\hline 17. Reading BBS & 53 \\
\hline 18. Listen to program creation assignments & 52 \\
\hline 19. Asking a teacher questions about program creation assignments & 70 \\
\hline 20. Asking TA questions about program creation assignments & 62 \\
\hline 21. Asking friends questions about program creation assignment & 126 \\
\hline 22. Deciding the contents of program to create & 58 \\
\hline 23. Examine the contents of program to create & 130 \\
\hline 24. Thinking about specifications about self-imposed assignment & 135 \\
\hline 25. Revising specifications about self-imposed assignment & 58 \\
\hline 26. Programming in reference to the contents examined & 176 \\
\hline 27. Summarizing in a report about the program created & 47 \\
\hline 28. Evaluating a program of another & 62 \\
\hline 29. Executing a program of another person and evaluating it & 36 \\
\hline 30. Revising a program in reference to peer evaluation & 101 \\
\hline 31. Revising self-program in reference to peer programs & 35 \\
\hline 32. Evaluating attitude related to abilities & 9 \\
\hline 33. Others & 59 \\
\hline Total & 3733 \\
\hline
\end{tabular}


Table-4. Number of effective activities chosen for awareness

\begin{tabular}{|c|c|}
\hline Awareness & Total \\
\hline (1) Interest in and curiosity about computers & 73 \\
\hline (2) Understanding of computers & 83 \\
\hline (3) Computer operation skills & 76 \\
\hline (4) Computer usage methods and broadening of situations & 72 \\
\hline (5) Ability to set challenges, ability to discover problems & 75 \\
\hline (6) Ability to plan, to do things in a planned manner & 76 \\
\hline (7) Cultivation of understanding of knowledge learned & 71 \\
\hline (8) Ability to study by oneself, ability to learn & 75 \\
\hline (9) Ability to gather information, ability to conduct research & 76 \\
\hline (10) Ability to sort through related information or data & 72 \\
\hline (11) Ability to analyse information & 65 \\
\hline (12) Ability to express thoughts in writing & 68 \\
\hline (13) Ability to express thoughts through media other than writing & 64 \\
\hline (14) Ability to talk to and explain to others comprehensively & 66 \\
\hline (15) Ability to make presentations & 62 \\
\hline (16) Ability to listen to others and to ask questions to others & 64 \\
\hline (17) Communication ability & 64 \\
\hline (18) Ability to appropriately self-evaluate one's thoughts & 68 \\
\hline (19) Ability to appropriately evaluate other people's thoughts & 65 \\
\hline (20) Ability to correct and improve on one's own thoughts & 67 \\
\hline (21) Ability to pursue matters deeply, ability to explore matters & 62 \\
\hline (22) Ability to execute, ability to practice, ability to put into action & 69 \\
\hline (23) Ability to cooperate and to learn concertedly & 58 \\
\hline (24) Sense of accomplishment, sense of satisfaction & 62 \\
\hline (25) Sense of fulfilment, sense of achievement & 63 \\
\hline (26) Ability to solve problems & 67 \\
\hline (27) Ability to construct and create knowledge & 66 \\
\hline (28) Ability to think, consider and come up with ideas by oneself & 64 \\
\hline (29) Creativity/ability to create & 60 \\
\hline (30) Interest in and curiosity about this field & 66 \\
\hline (31) Interest in programming & 76 \\
\hline (32) Knowledge of programming & 76 \\
\hline (33) Desire to learn about programming & 69 \\
\hline (34) Desire to try problems & 70 \\
\hline (35) Ability to think about a problem in stages & 69 \\
\hline (36) Ability to express an idea as an algorithm & 68 \\
\hline (37) Ability to think about algorithms & 69 \\
\hline (38) Ability to review the flow of an algorithm & 70 \\
\hline (39) Ability to improve algorithms & 70 \\
\hline (40) Ability to express ideas with PHP & 73 \\
\hline (41) Ability to debug PHP programs & 65 \\
\hline (42) Ability to configure test data & 62 \\
\hline (43) Ability to work to improve a program & 65 \\
\hline (44) Ability to write reports about programs & 64 \\
\hline (45) Ability to understand other people's ideas & 66 \\
\hline (46) Ability to read other student's programs & 63 \\
\hline (47) Ability to read other people's reports & 63 \\
\hline (48) Ability to express personal ideas using a computer & 63 \\
\hline (49) Ability to collaborate on problems & 67 \\
\hline (50) Ability to learn for a problem positively & 63 \\
\hline (51) Ability to keep working on a problem until it is finished & 67 \\
\hline (52) Knowledge of JavaScript syntax & 68 \\
\hline (53) Knowledge for running JavaScript & 65 \\
\hline (54) Knowledge of correcting program errors & 72 \\
\hline (55) Knowledge of programming techniques & 71 \\
\hline Total & 3733 \\
\hline
\end{tabular}


Cluster analysis was conducted by taking awareness as its case and activities as variables in this table using the Ward method. Awareness was divided into four clusters from the dendrogram when cutting dendrogram at level of dissimilarity 7 as shown in Figure 1. These were called Groups I - IV. Horizontal axis in Figure 1 is dis-similarity, and a vertical axis is awareness.

Group I has awareness in the following 27 categories: "(35) Ability to think about a problem in stages, (36) Ability to express an idea as an algorithm, (37) Ability to think about algorithms, (38) Ability to review the flow of an algorithm, (24) Sense of accomplishment, sense of satisfaction, (25) Sense of fulfilment, (43) Ability to work to improve a program, (39) Ability to improve algorithms, (40) Ability to express ideas with PHP, (41) Ability to debug PHP programs, (42) Ability to configure test data, (26) Ability to solve problems, (5) Ability to set challenges, ability to discover problems, (6) Ability to plan, to do things in a planned manner, (9) Ability to gather information, ability to conduct research, (34) Desire to try problems, (29) Ability to create, (48) Ability to express personal ideas using a computer, (27) Ability to construct and create knowledge, (28) Ability to think, consider and come up with ideas by oneself, (10) Ability to sort through related information or data, (11) Ability to analyze information, (8) Ability to study by oneself, ability to learn, (21) Ability to pursue matters deeply, ability to explore matters, (3) Computer operation skills, (4) Computer usage methods and broadening of situations and (7) Cultivation of understanding of knowledge learned." Average frequency of enumerated activities that were useful for awareness in these 27 categories was 68.4, nearly same as the overall average value and with middle level frequency. Of the above, the frequency of (3), (5), (6), (8) and (9) was comparatively high. From these, Group I can be summarized as "I. Awareness relating to skills to gather information, to set challenges and to learn according to the plan."

Group II has awareness in the following 14 categories: “(18) Ability to appropriately self-evaluate one's thoughts, (20) Ability to correct and improve on one's own thoughts, (12) Ability to express thoughts in writing, (44) Ability to write reports about programs, (14) Ability to talk to and explain to others comprehensively, (15) Ability to make presentations, (13) Ability to express thoughts through media other than writing, (16) Ability to listen to others and to ask questions to others, (17) Communication ability, (22) Ability to execute, ability to practice, ability to put into action, (51) Ability to keep working on a problem until it is finished, (23) Ability to cooperate and to learn concertedly, (49) Ability to collaborate on problems, and (50) Ability to learn for a problem positively." Average frequency of enumerated activities that were useful for awareness in these 14 categories was 65.1 and slightly less than the overall average value. Of the above, the frequency of (12), (18), (20), (22), (49) and (51) was comparatively high. Therefore Group II can be summarized as "II. Awareness relating to skills to collaborate on problems, to correct on one's own thoughts, to execute and to express thoughts."

Group III has awareness in four categories: “(46) Ability to read other student's programs, (47) Ability to read other people's reports, (45) Ability to understand other people's ideas, and (19) Ability to appropriately evaluate other people's thoughts." Average frequency of enumerated activities that were useful for awareness in these four categories was 64.3. Group III had slightly less than the overall average value. The frequency of the four categories was approximately same. From these, Group III can be summarized as "III. Awareness relating to skills to understand programs and reports by reading them.

Group IV has awareness in ten categories: “(52) Knowledge of JavaScript syntax, (53) Knowledge for running JavaScript, (33) Desire to learn about programming, (31) Interest in programming, (32) Knowledge of programming, (54) Knowledge of correcting program errors, (55) Knowledge of programming techniques, (30) Interest in and curiosity about this field, (1) Interest in and curiosity about computers, and (2) Understanding of computers." Average frequency of enumerated activities that were useful for awareness in these ten categories was 71.9. Group IV had the highest average frequency. Of the above, the frequency of (2), (31), (32) and (55) was comparatively high. Therefore Group IV can be summarized as "IV. Awareness relating to skills to interest in programming and to understand knowledge." 
(35) Ability to think about a problem in stages

(36) Ability to express an idea as an algorithm

(37) Ability to think about algorithms

(38) Ability to review the flow of an algorithm

24) Sense of accomplishment, sense of satisfaction

(25) Sense of fulfilment, sense of achievement

(43) Ability to work to improve a program

39) Ability to improve algorithms

(40) Ability to express ideas with PHP

(41) Ability to debug PHP programs

(42) Ability to configure test data

(26) Ability to solve problems

(5) Ability to set challenges, ability to discover problems

(6) Ability to plan, to do things in a planned manner

(9) Ability to gather information, ability to conduct research

(34) Desire to try problems

(29) Creativity/ability to create

(48) Ability to express personal ideas using a computer

(27) Ability to construct and create knowledge

(28) Ability to think, consider and come up with ideas by oneself

(10) Ability to sort through related information or data

(11) Ability to analyse information

(8) Ability to study by oneself, ability to learn

(21) Ability to pursue matters deeply, ability to explore matters

(3) Computer operation skills

(4) Computer usage methods and broadening of situations

(7) Cultivation of understanding of knowledge learned

(18) Ability to appropriately self-evaluate one's thoughts

(20) Ability to correct and improve on one's own thoughts

(12) Ability to express thoughts in writing

(44) Ability to write reports about programs

(14) Ability to talk to and explain to others comprehensively

(15) Ability to make presentations

(13) Ability to express thoughts through media other than writing

(16) Ability to listen to others and to ask questions to others

(17) Communication ability

(22) Ability to execute, ability to practice, ability to put into action

(51) Ability to keep working on a problem until it is finished

(23) Ability to cooperate and to learn concertedly

(49) Ability to collaborate on problems

(50) Ability to learn for a problem positively

(46) Ability to read other student' s programs

(47) Ability to read other people's reports

(45) Ability to understand other people's ideas

(19) Ability to appropriately evaluate other people's thoughts

(52) Knowledge of JavaScript syntax

(53) Knowledge for running JavaScript

(33) Desire to learn about programming

(31) Interest in programming

(32) Knowledge of programming

(54) Knowledge of correcting program errors

(55) Knowledge of programming techniques

(30) Interest in and curiosity about this field

(1) Interest in and curiosity about computers

(2) Understanding of computers

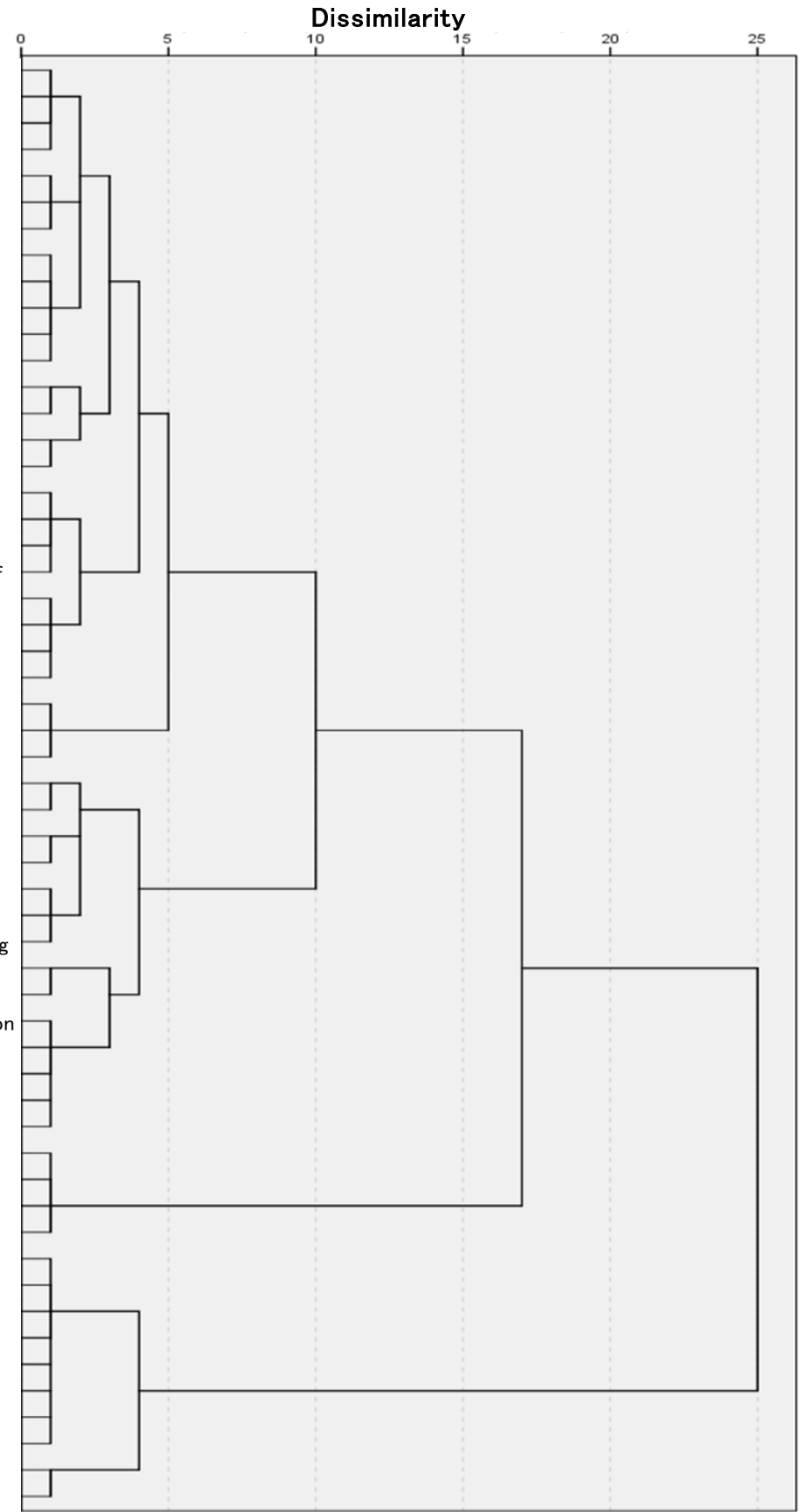

Figure-1. Dendrogram of awareness clusters determined using cluster analysis

3.2. Classification of Activities through Cluster Analysis Using the Number of Activities That are Useful in Improving Awareness

The same cross-tabulation table was also analysed by cluster analysis with Ward's method in the opposite direction from the previous section, using activities as cases and awareness as variables. The obtained dendrogram was then used to classify activities into Clusters 1 through 3 when cutting dendrogram at level of dissimilarity 2 as shown in Figure 2. These were called Groups $1-3$.

Group 1 comprised the following 21 activities: "20. Asking TA questions about program creation assignments, 33. Others, 19. Asking a teacher questions about program creation assignments, 18. Listen to program creation assignments, 08. Learning through lecture slides, 17. Reading BBS, 12. Studying for the final exam, 22. Deciding the contents of program to create 25. Revising specifications about self-imposed assignment, 14. Using Excel, 15. Using Word, 09. Evaluating about learning through lecture slides, 32. Evaluating attitude related to abilities, 13. Asking using mail, 04. Asking a teacher questions about lecture topics, 11. Evaluating about learning through exercise problems, 16. Writing into BBS, 29. Executing a 
program of another person and evaluating it, 31. Revising self-program in reference to peer programs, 27. Summarizing in a report about the program created, and 28. Evaluating a program of another person." The number of times an activity was listed ranged from 9 to 70 times. The most frequently listed activities were 19, 20, 22, 25, and 28. Based on its constituent items, Group 1 can be characterized as "1. Activities related to asking questions, revising, and evaluating." These activities were listed 875 times.

Group 2 comprised the following 11 activities: “21. Asking friends questions about program creation assignments, 30. Revising a program in reference to peer evaluation, 24. Thinking about specifications about self-imposed assignment, 05. Preparing, 06. Reviewing, 23. Examine the contents of program to create, 02. Getting an image of the whole lecture, 26. Programming in reference to the contents examined, 03 Asking friends questions about lecture topics, 10. Learning through exercise problems, and 07. Studying using the textbook." The number of times an activity was listed ranged from 101 to 276 times. The most frequently listed activities included 3, 7, 10, and 26. Based on its constituent items, Group 2 can be characterized as " 2. Activities that involve studying with the textbook and practice problems, and creating programs." These activities were listed 1752 times.

Group 3 consisted of one activity: "1. Listening to lectures.” Therefore, Group 3 can be characterized as "3. Activities related to listening to lectures." This activity was listed 1106 times. "1. Listening to lectures" was the most listed item of all 33 items by a considerable amount, indicating that it was the most helpful activity.

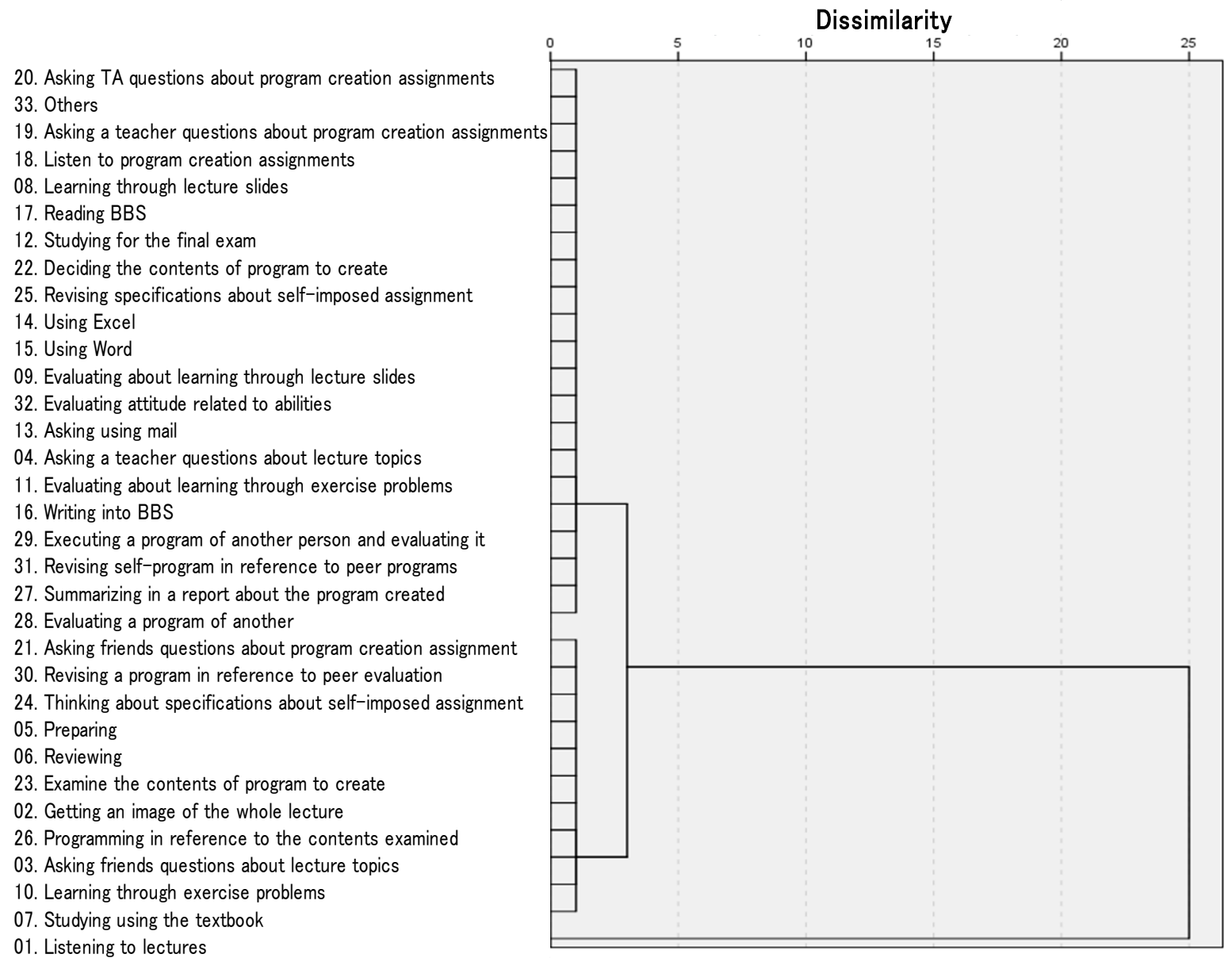

01 . Listening to lectures

Figure-2. Dendrogram of activity clusters determined using cluster analysis.

\subsection{Results from Analysis of Activities that Help to Improve Awareness}

The cross-tabulation table of awareness and activities was 55 rows by 33 columns. The number of times activities were listed in each cluster obtained in the above section was totalled, and results are shown in the upper-left side of Table 5. Chi-square tests were performed using this table as a $4 \times 3$ contingency table. This showed that there was a significant bias regarding the number of times activities were listed $\left(\chi^{2}(6)=97.6, p\right.$ $<.001)$. Results from residual analysis are shown in the bottom-left side of Table 5. Cells that contained statistically significant values with positive residuals are indicated with an asterisk on the bottom-right side of Table 5 .

This analysis revealed that the activity "1. Activities related to asking questions, revising, and evaluating" was helpful in improving "II. Awareness relating to skills to collaborate on problems, to correct on one's own 
thoughts, to execute and to express thoughts" and "III. Awareness relating to skills to understand programs and reports by reading them."

"2. Activities that involve studying with the textbook and practice problems, and creating programs" were helpful in improving "I. Awareness relating to skills to gather information, to set challenges and to learn according to the plan."

“3. Activities related to listening to lectures" were helpful in improving "IV. Awareness relating to skills to interest in programming and to understand knowledge."

Table-5. Chi-square analysis and residual analysis for cross-tabulation of awareness and activity clusters in the class of PHP and JavaScript programming. SS

\begin{tabular}{|c|c|c|c|c|c|c|c|}
\hline & \multicolumn{4}{|c|}{ Observed frequency } & \multicolumn{3}{|c|}{ Expected frequency } \\
\hline Clusters of awareness & 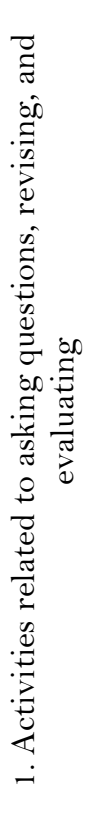 & 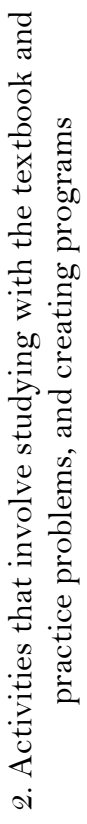 & 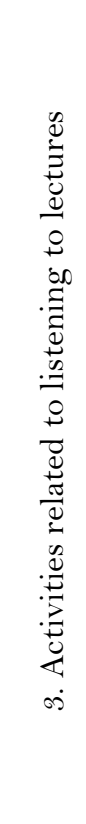 & 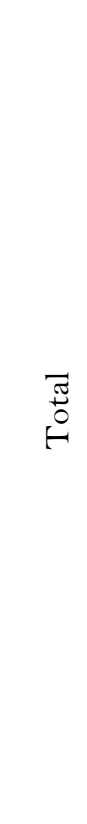 & 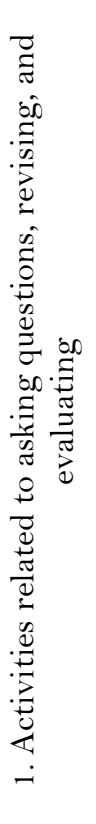 & 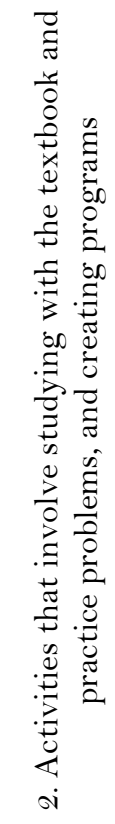 & 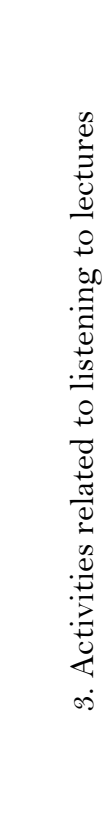 \\
\hline $\begin{array}{l}\text { I. Awareness relating to skills to gather } \\
\text { information, to set challenges and to learn } \\
\text { according to the plan }\end{array}$ & 405 & 904 & 537 & 1846 & 432.7 & 866.4 & 546.9 \\
\hline $\begin{array}{l}\text { II. Awareness relating to skills to collaborate on } \\
\text { problems, to correct on one's own thoughts, to } \\
\text { execute and to express thoughts }\end{array}$ & 259 & 421 & 231 & 911 & 213.5 & 427.6 & 269.9 \\
\hline $\begin{array}{l}\text { III. Awareness relating to skills to understand } \\
\text { programs and reports by reading them }\end{array}$ & 103 & 88 & 66 & 257 & 60.2 & 120.6 & 76.1 \\
\hline $\begin{array}{l}\text { IV. Awareness relating to skills to interest in } \\
\text { programming and to understand knowledge }\end{array}$ & 108 & 339 & 272 & 719 & 168.5 & 337.4 & 213.0 \\
\hline \multirow[t]{2}{*}{ Total } & 875 & 1752 & 1106 & 3733 & 875.0 & 1752.0 & 1106.0 \\
\hline & \multicolumn{3}{|c|}{ Adjusted residual } & & \multicolumn{3}{|c|}{ Significance probability } \\
\hline $\begin{array}{l}\text { I. Awareness relating to skills to gather } \\
\text { information, to set challenges and to learn } \\
\text { according to the plan }\end{array}$ & -2.1 & 2.5 & -0.7 & & & * & \\
\hline $\begin{array}{l}\text { II. Awareness relating to skills to collaborate on } \\
\text { problems, to correct on one's own thoughts, to } \\
\text { execute and to express thoughts }\end{array}$ & 4.1 & -0.5 & -3.2 & & $* * *$ & & \\
\hline $\begin{array}{l}\text { III. Awareness relating to skills to understand } \\
\text { programs and reports by reading them }\end{array}$ & 6.5 & -4.2 & -1.4 & & **** & & \\
\hline \multirow[t]{2}{*}{$\begin{array}{l}\text { IV. Awareness relating to skills to interest in } \\
\text { programming and to understand knowledge }\end{array}$} & -5.9 & 0.1 & 5.4 & & & & *** $*$ \\
\hline & & & & & \multicolumn{3}{|c|}{ **** $\mathrm{p}<.001, *$ $\mathrm{p}<.05$} \\
\hline
\end{tabular}

\subsection{Comparison between Activities that Help to Improve Awareness for PHP and JavaScript}

The cross-tabulation table of awareness and activities for PHP was 55 rows by 33 columns. The number of times activities were listed in each cluster obtained in the above section was totalled, and results are shown 
on the upper-left side of Table 6 . Chi-square tests were performed using this table as a $4 \times 3$ contingency table. This showed that there was a significant bias regarding the number of times activities were listed $\left(\chi^{2}(6)=\right.$ $14.7, \mathrm{p}<.05)$. Results from residual analysis are shown on the bottom-left side of Table 6. Cells that contained statistically significant values with positive residuals are indicated with an asterisk $(*)$ on the bottom-right side of Table 6.

This analysis revealed that the activity " 1 . Activities related to asking questions, revising, and evaluating" was helpful in improving "III. Awareness relating to skills to understand programs and reports by reading them."

"3. Activities related to listening to lectures" were helpful in improving "IV. Awareness relating to skills to interest in programming and to understand knowledge."

The cross-tabulation table of awareness and activities for JavaScript was 55 rows by 33 columns. The number of times activities were listed in each cluster obtained in the above section was totalled, and results are shown on the upper-left side of Table 7 . Chi-square tests were performed using this table as a $4 \times 3$ contingency table. This showed that there was a significant bias regarding the number of times activities were listed $\left(\chi^{2}(6)=121.9, \mathrm{p}<.001\right)$. Results from residual analysis are shown on the bottom-left side of Table 7 . Cells that contained statistically significant values with positive residuals are indicated with an asterisk $(*)$ on the bottom-right side of Table 7 .

The useful activity in the JavaScript was the same results as explained in 3.3 section from results of Table 7. The classes of PHP and JavaScript programming were developed by the same activities. It was found that the activities in the JavaScript worked more usefully than that in PHP. Differences between both classes are the following two points. "1. Activities related to asking questions, revising, and evaluating" in the JavaScript programming were helpful in improving "II. Awareness relating to skills to collaborate on problems, to correct on one's own thoughts, to execute and to express thoughts." "2. Activities that involve studying with the textbook and practice problems, and creating programs" were helpful in improving "I. Awareness relating to skills to gather information, to set challenges and to learn according to the plan." However, these activities in the PHP programming were less helpful than those in the JavaScript.

Table-6. Chi-square analysis and residual analysis for cross-tabulation of awareness and activity clusters in the class of PHP programming.

\begin{tabular}{|c|c|c|c|c|c|c|c|}
\hline & \multicolumn{4}{|c|}{ Observed frequency } & \multicolumn{3}{|c|}{ Expected frequency } \\
\hline Clusters of activities & 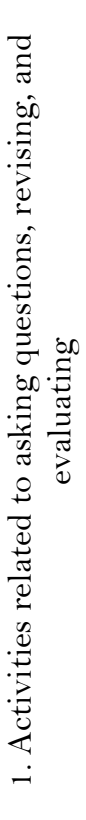 & 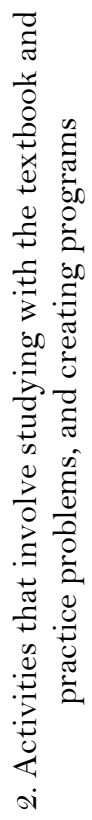 & 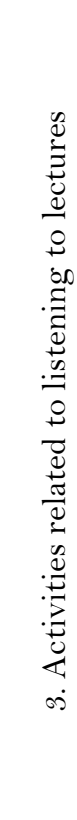 & 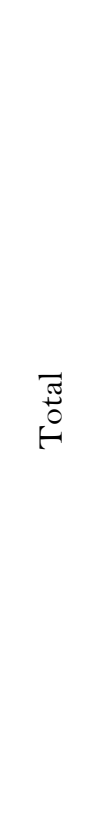 & 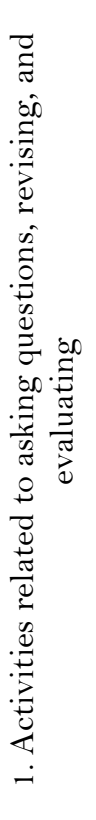 & 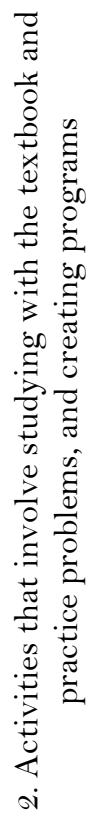 & 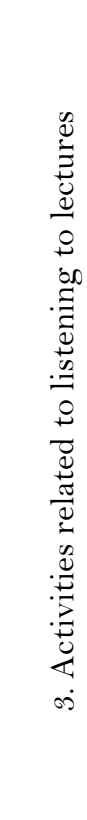 \\
\hline $\begin{array}{l}\text { I. Awareness relating to skills to gather } \\
\text { information, to set challenges and to learn } \\
\text { according to the plan }\end{array}$ & 239 & 517 & 351 & 1107 & 252.4 & 503.7 & 350.9 \\
\hline $\begin{array}{l}\text { II. Awareness relating to skills to collaborate on } \\
\text { problems, to correct on one's own thoughts, to } \\
\text { execute and to express thoughts }\end{array}$ & 135 & 248 & 157 & 540 & 123.1 & 245.7 & 171.2 \\
\hline $\begin{array}{l}\text { III. Awareness relating to skills to understand } \\
\text { programs and reports by reading them }\end{array}$ & 49 & 59 & 46 & 154 & 35.1 & 70.1 & 48.8 \\
\hline IV. Awareness relating to skills to interest in & 84 & 188 & 151 & 423 & 96.4 & 192.5 & 134.1 \\
\hline
\end{tabular}




\begin{tabular}{l|r|r|r|r|r|r|r}
\hline programming and to understand knowledge & & & & & & & \\
\hline \multicolumn{1}{c|}{ Total } & 507 & 1012 & 705 & 2224 & 507.0 & 1012.0 & 705.0 \\
\hline $\begin{array}{l}\text { I. Awareness relating to skills to gather } \\
\text { information, to set challenges and to learn } \\
\text { according to the plan }\end{array}$ & -1.1 & 1.0 & 0.0 & & & & \\
\hline $\begin{array}{l}\text { II. Awareness relating to skills to collaborate on } \\
\text { problems, to correct on one's own thoughts, to } \\
\text { execute and to express thoughts }\end{array}$ & 1.3 & 0.2 & -1.4 & & & & \\
\hline $\begin{array}{l}\text { III. Awareness relating to skills to understand } \\
\text { programs and reports by reading them }\end{array}$ & 2.7 & -1.9 & -0.5 & & $* *$ & & \\
\hline $\begin{array}{l}\text { IV. Awareness relating to skills to interest in } \\
\text { programming and to understand knowledge }\end{array}$ & -1.5 & -0.5 & 1.8 & & & & + \\
\hline
\end{tabular}

Table-7. Chi-square analysis and residual analysis for cross-tabulation of awareness and activity clusters in the class of JavaScript programming.

\begin{tabular}{|c|c|c|c|c|c|c|c|}
\hline & \multicolumn{4}{|c|}{ Observed frequency } & \multicolumn{3}{|c|}{ Expected frequency } \\
\hline Clusters of awareness & 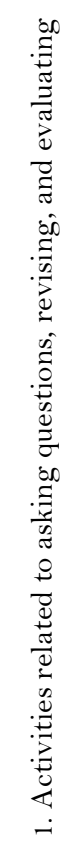 & 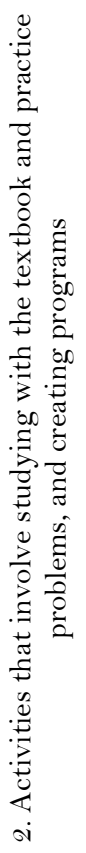 & 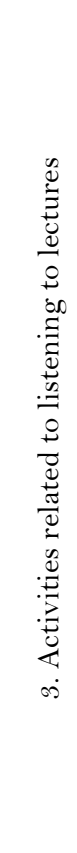 & 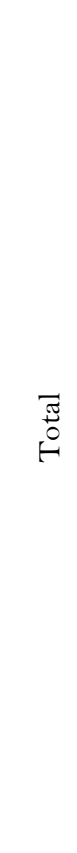 & 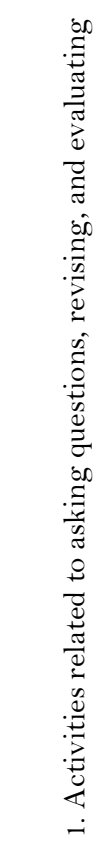 & 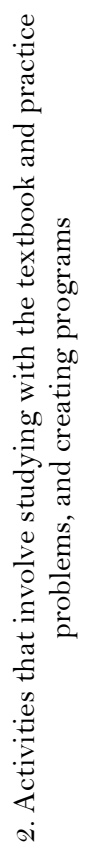 & 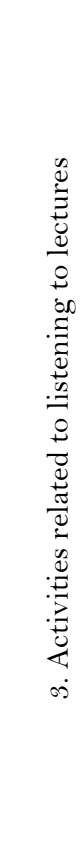 \\
\hline $\begin{array}{l}\text { I. Awareness relating to skills to gather information, to } \\
\text { set challenges and to learn according to the plan }\end{array}$ & 166 & 387 & 186 & 739 & 180.2 & 362.4 & 196.4 \\
\hline $\begin{array}{l}\text { II. Awareness relating to skills to collaborate on } \\
\text { problems, to correct on one's own thoughts, to execute } \\
\text { and to express thoughts }\end{array}$ & 124 & 173 & 74 & 371 & 90.5 & 181.9 & 98.6 \\
\hline $\begin{array}{l}\text { III. Awareness relating to skills to understand programs } \\
\text { and reports by reading them }\end{array}$ & 54 & 29 & 20 & 103 & 25.1 & 50.5 & 27.4 \\
\hline $\begin{array}{l}\text { IV. Awareness relating to skills to interest in } \\
\text { programming and to understand knowledge }\end{array}$ & 24 & 151 & 121 & 296 & 72.2 & 145.2 & 78.7 \\
\hline Total & 368 & 740 & 401 & 1509 & 368.0 & 740.0 & 401.0 \\
\hline & \multicolumn{3}{|c|}{ Adjusted residual } & & \multicolumn{3}{|c|}{ Significance probability } \\
\hline $\begin{array}{l}\text { I. Awareness relating to skills to gather information, to } \\
\text { set challenges and to learn according to the plan }\end{array}$ & -1.4 & 2.0 & -1.0 & & & * & \\
\hline $\begin{array}{l}\text { II. Awareness relating to skills to collaborate on } \\
\text { problems, to correct on one's own thoughts, to execute } \\
\text { and to express thoughts }\end{array}$ & 4.2 & -1.0 & -3.1 & & **** & & \\
\hline $\begin{array}{l}\text { III. Awareness relating to skills to understand programs } \\
\text { and reports by reading them }\end{array}$ & 6.7 & -4.2 & -1.7 & & ***** & & \\
\hline \multirow[t]{2}{*}{$\begin{array}{l}\text { IV. Awareness relating to skills to interest in } \\
\text { programming and to understand knowledge }\end{array}$} & -6.8 & 0.7 & 5.9 & & & & ***** \\
\hline & & & & & \multicolumn{3}{|c|}{ **** $\mathrm{p}<.001, *{ }^{*} \mathrm{p}<.05$} \\
\hline
\end{tabular}




\section{Discussion}

The lecture course in this report was on programming with JavaScript which was given in Fiscal 2014. Class in PHP programming was given in Fiscal 2011 and the effects of the class have been reported (Miyajij \& Yoshida, 2014b; Miyajip, 2015; Miyajis, 2013; Miyajiv \& Yoshida, 2014a). Of these, it was described that the general awareness did not improve much while the awareness related to programming improved, and it was considered that one of the reasons might have been because the exercise problems were too difficult (Miyajia, 2017). The numbers of students responding to the surveys on lecture courses in PHP and JavaScript programming were 23 and 18, respectively.

Therefore in this study, which was the same programming class even though the language was Java Script, to check this was decided by making the exercise problems easier. Here, the description was replaced with PHP in evaluation items. The changes in awareness on programming by PHP is already reported (Miyajiv \& Yoshida, 2014a). The changes in awareness on programming by PHP and the changes in awareness in Java Script are compared.

The result of significance test on average evaluation values in each lecture course before the lecture course, after the lecture course and growth (after - before) showed that the number of items with significant difference (for general awareness and awareness related to programming) in PHP and JavaScript programming were (5, $17)$ and $(15,19)$, respectively. Based on these, it is assumed that the awareness improved in more general items in JavaScript programming after the lecture course. In addition, it seems that there was little difference in the growth of awareness related to programming according to awareness between PHP and JavaScript programming (Miyajia, 2017).

Next, t-test between average evaluation values from PHP and JavaScript before the lecture course, after the lecture course and growth (after - before) was conducted. As a consequence, significant difference was observed only for Item (53) before the lecture course. Tendency for significant difference was observed for Item (13). For average evaluation values after the lecture course, there was significant difference for Items (19), (20), (23), (24), (35), and (45). There was tendency for significant difference in Items (8), (18), and (44). Regarding average evaluation value for growth, significant difference was observed only for Item (53). Tendency for significant difference was observed for Item (23).

Based on this, it was found that there was little difference in the growth of average evaluation values between PHP and JavaScript programming. Items with significant difference or tendency for significant difference were "(53) Knowledge to execute Java Script (PHP)" and “(23) Ability to cooperate and learn cooperatively." For Item (53), nearly all students were able to complete the program for exercise problems using JavaScript as the problems are relatively easier compared to PHP. It is therefore assumed that they felt that “(53) Knowledge to execute Java Script" improved better. In addition, it is assumed that Item (23) improved as students did voluntary themes, executed and evaluated one another's work and also stating comments. The students seemed especially to feel more strongly that mutual evaluation helped since they were able to complete nearly all programs in JavaScript programming.

It was found that the activities in JavaScript class worked more usefully than that in PHP class. Differences between both classes are outcome of two activity clusters 1 and 2 . The activity clusters 1 and 2 in JavaScript improved the awareness clusters II and I respectively. However those in PHP did not improve them. As one of the reasons, it is supposed that there are less opportunities which foster skills to collaborate on problems, to correct on one's own thoughts and to express thoughts because activities to ask questions, revise, and evaluate in PHP class are less than those in JavaScript class.

\section{Conclusion}

In JavaScript programming education in a university, lectures and exercises were given to have the students submit programs and reports for exercise problems. In the final two weeks, programs for voluntary themes were developed for mutual evaluation, correction with reference to the evaluation and another mutual evaluation to check if they could correct properly. Surveys on degree of term recognition and awareness were conducted before and after the course. The useful activities for improving awareness were investigated on the same survey form about the awareness is taken after the lecture course.

The following were found in this study:

(1) The activity "1. Activities related to asking questions, revising, and evaluating" was helpful in improving "II. Awareness relating to skills to collaborate on problems, to correct on one's own thoughts, to execute and to express thoughts" and "III. Awareness relating to skills to understand programs and reports by reading them."

(2) The activity " 2 . Activities that involve studying with the textbook and practice problems, and creating programs" was helpful in improving "I. Awareness relating to skills to gather information, to set challenges and to learn according to the plan."

(3) The activity "3. Activities related to listening to lectures" was helpful in improving "IV. Awareness relating to skills to interest in programming and to understand knowledge."

(4) The activities in the JavaScript class which easier exercise problems was given worked more usefully than that in the PHP class. 
The author would like to make further examination in the future to classify the students as well as evaluation items through multivariate analysis in order to identify helpful activities and difference in instruction methods depending on the student group. The author would also like to conduct analysis that may lead to findings other than those from this study.

\section{Acknowledgements}

This work was supported by JSPS KAKENHI Grant Numbers JP25350364, JP15Ho2919, JP15Ko1 104. The author would like to express appreciation to the students who were surveyed and who helped collect educational information.

\section{References}

Anku. (2011). Illustrated book of java script. Tokyo. Japan: Shoeisha.

Bersin, J. (2004). The blended learning book: Best practices, proven methodologies, and lessons learned. San Francisco. USA: John Wiley \& Sons, Inc.

Central Council for Education. (2012). Toward qualitative change of the university education to build a new future $\sim$ aiming at the university which can nourish the ability to continue learning throughout the life and think independently. (Report).

Miyaji, I. (2009). Toward blended learning from E-learning. Tokyo, Japan: Kyouritu-Shuppan.

Miyajia, I. (2017). Comparison of term recognition and awareness in blended classes of JavaScript and PHP programming. Asian Education Studies, 2(1), 28-39. Available at: 10.20849/aes.v2i1.108.

Miyajic, I., \& Yoshida, K. (2005). The practice and learning effect of education by blending of lecture and e-learning. Transactions of Japanese Society for Information and Systems in Education, 22(4), 230-239.

Miyajii, I. (2016). Change of term recognition and awareness in blended class of JavaScript programming. Proceeding of SITE 2016, Society for Information Technology \& Teacher Education International Conference 2016, Savannah, GA, USA, 727-732.

Miyajij, I., \& Yoshida, K. (2014b). Categories of attitude and student determined by cluster analysis of the attitudes toward programming abilities in a blended class. International Journal Cross-Disciplinary Subjects in Education, 5(4), 18451853. Available at: 10.20533/ijcdse.2042.6364.2014.0257.

Miyajim, I., Yoshida, K., \& Naruse, Y. (2007). The effects of blending e-learning and lectures utilizing a structured notebook. Transactions of Japanese Society for Information and Systems in Education, 4(3), 208-215.

Miyajip, I. (2015). Useful activities for improving the attitudes and characteristic of student groups in blended class of programming course. GSTF Journal on Education, 3(1), 29-38.

Miyajis, I. (2013). Consciousness and recognition degree of terms in programming through blended classes (pp. 24-28). Proceedings of Japanese Society for Science Education, Chugoku Branch Symposium, Toward Blended Learning from E-learning (part 5).

Miyajiv, I., \& Yoshida, K. (2014a). Improvement of the attitudes and their familiarity with terminology of a programming course with a blended learning structure. Paper presented at the Proceedings of the Canada International Conference on Education, CICE 2014, Sydney, Canada.

Shinkai, J., \& Miyaji, I. (2011). Effects of blended instruction on C programming education. Transactions of Japanese Society for Information and Systems in Education, 28(2), 151-162. 